\title{
Théologiques
}

\section{Psalm of Anger to a Patriarchal god}

\section{Sheila A. Redmond}

Volume 8, numéro 2, automne 2000

Le pouvoir

URI : https://id.erudit.org/iderudit/005024ar

DOI : https://doi.org/10.7202/005024ar

Aller au sommaire du numéro

Éditeur(s)

Faculté de théologie de l'Université de Montréal

ISSN

1188-7109 (imprimé)

1492-1413 (numérique)

Découvrir la revue

Citer ce document

Redmond, S. A. (2000). Psalm of Anger to a Patriarchal god. Théologiques, 8(2),

33-34. https://doi.org/10.7202/005024ar d'utilisation que vous pouvez consulter en ligne.

https://apropos.erudit.org/fr/usagers/politique-dutilisation/ 


\title{
Psalm of Anger to a Patriarchal god ${ }^{\star}$
}

\author{
Sheila A. REDMOND
}

\section{God:}

You abandoned me

You made promises you couldn't keep

You were supposed to be all powerful, all knowing -

And more than that

You were supposed to love me and take care of me

Just like you took care of the lillies and the sparrows.

You let me down, you lied to me and I was good, And I loved you and I got saved and

You were supposed to make everything better!

The pain and the hurt and the guilt were supposed to go away.

But they didn't.

And I tried and I cried and I looked for you and what did I find

You demanded a man kill his own son to prove his faithfulness.

You destroyed a man on a bet and didn't even have the decency to tell him why

You just terrified him into submission.

You even killed your own child!

Don't tell me you couldn't have done things differently. You seem to delight in putting your children through hell -

Hell is for children!

The best you can do is tell me I need to be forgiven -

FOR WHAT!

* Sheila A. ReDmond, «Confrontation Between the Christian God and an Abused Child: Twenty-Five Years Later», dans Church Council on Justice and Corrections; Canadian Council on Social Development, Family violence in a Patriarchal Society: A Challenge to the Church, Ottawa, 1987. 
I didn't ask to be born in original sin.

I didn't ask to be raped and beaten and destroyed:

I trusted you and I believed in you.

When the going got rough, you abandoned me!

I didn't leave you, you left me.

I would rather spend eternity in hell than spend it with you, You god of Abraham, Isaac, Jacob, Moses, Jesus, Peter and Paul.

I don't need forgiveness, you do!

And I will never, never repent..

You owe me my life back and you can't even admit you were wrong.

You are a god who asks too much.

I am buying my soul back. I can never trust you again.

That would be like a battered woman going back to her husband

Or a beaten child needing the love and approval of the parent

who committed the crimes.

You want us to come to you as children.

No wonder!

Only a child would be naive enough to fall for your lies and stupid promises.

I may forgive you, you pitiful god of my childhood

But I will never forget how you abandoned me.

And I will never allow myself to be destroyed by you or you creations Again!

Where were You when I needed You? 